\title{
Sortilin-Related Receptor
}

National Cancer Institute

\section{Source}

National Cancer Institute. Sortilin-Related Receptor. NCI Thesaurus. Code C126511.

Sortilin-related receptor (2214 aa, $248 \mathrm{kDa}$ ) is encoded by the human SORL1 gene. This protein is involved in both endocytosis and protein trafficking. 